\title{
Trends in a Cohort of HIV-infected Pregnant Women in Rio de Janeiro, 1996-2004
}

\section{Tendências temporais observadas em uma coorte de gestantes infectadas pelo HIV acompanhadas no Rio de Janeiro de 1996 a 2004}

\section{Guilherme Amaral Calvet ${ }^{1}$ \\ Esaú Custódio João' \\ Karin Nielsen-Saines ${ }^{2}$ \\ Cynthia Braga Cunha' \\ Jacqueline Anita Menezes ${ }^{1}$ \\ Marcos Machado d'Ippolito ${ }^{3}$ \\ Maria Letícia Santos Cruz ${ }^{1}$ \\ Ezequias Batista Martins ${ }^{1}$ \\ Sônia Maria Santos Silva ${ }^{3}$ \\ Adriana Ferreira Medeiros' \\ Haroldo José Matos ${ }^{4}$ \\ 'Department of Infectious Diseases; Hospital dos Servidores do Estado, Rio de Janeiro, RJ, Brazil \\ 2David Geffen UCLA School of Medicine; Department of Pediatrics; Division of Infectious Diseases; Los Angeles, California \\ ${ }^{3}$ Department of Obstetrics; Hospital dos Servidores do Estado, Rio de Janeiro, RJ, Brazil \\ ${ }^{4}$ Department of Epidemiology; Hospital dos Servidores do Estado, Rio de Janeiro, RJ, Brazil}

Correspondence: Guilherme Amaral Calvet. Infectious Diseases Department - Hospital dos Servidores do Estado. Rua Sacadura Cabral 178, $5^{\circ}$ Andar - Anexo IV - Saúde - Rio de Janeiro, RJ, Brazil - CEP 20221-903. E-mail: guilherme@diphse.com.br

\section{Abstract}

Objective: To describe trends in sociodemographic, immunological and virological profiles and interventions to decrease the risk of mother-to-child HIV transmission. Methods: Retrospective cohort study conducted at a tertiary institution in Rio de Janeiro, Brazil from January 1996 to December 2004. Analysis was performed by stratification in three time periods: 19961998 (P1), 1999-2001 (P2) and 2002-2004 (P3). Results: In 9 years, 622 pregnancies occurred. Complications included: maternal mortality $0.3 \%$, stillbirths $2.5 \%$, miscarriages $0.6 \%$, neonatal mortality $1.1 \%$, prematurity $9.9 \%$, low birth weight (LBW) $16.5 \%$, congenital malformations $2.2 \%$. The number of HIV-infected pregnant patients grew threefold over time reflecting increased prevalence of disease and patient identification. HIV diagnosis before pregnancy increased from $30 \%$ in $\mathrm{P} 1$ to $45 \%$ in P3. The proportion of pregnant women receiving highly active antiretroviral therapy increased from none (P1) to $88 \%(\mathrm{P} 3)$ with a significant trend towards women delivering at undetectable viral loads in later years despite a higher frequency of advanced disease. Scheduled cesarean deliveries increased from $35 \%$ in $\mathrm{P} 1$ to $48 \%$ in P3. Perinatal transmission rates were $2.4 \%$ with a decline from $3.5 \%$ in $\mathrm{P} 1$ to $1.6 \%$ in P3. Neonatal outcomes tended to remain constant or improve with time. A slight rise in LBW and congenital malformations were observed. Conclusions: During the observational period, HIV+ pregnant women presented with more advanced disease and lower socio-economic status. However, improved management of HIV-infected patients (associated with increased identification and increased availability of treatment) resulted into very low transmission rates similar to those of developed countries with overall improvement of patient outcomes.

Keywords: Mother-to-child HIV transmission. Antiretroviral therapy pregnancy. Cohort study Brazil. HIV. 


\section{Resumo}

Objetivos: Descrever as tendências temporais nas características sociodemográficas, imunológicas e virológicas e as das condutas utilizadas para reduzir o risco da transmissão mãe-filho do HIV. Métodos: Estudo de coorte retrospectivo em uma instituição de saúde terciária no Rio de Janeiro de janeiro de 1996 a dezembro de 2004. A análise utilizou a estratificação em três períodos de tempo: 1996-1998 (P1), 1999-2001 (P2) e 2002-2004 (P3). Resultados: Em 9 anos, 622 gestações foram acompanhadas. As complicações foram: mortalidade materna $0,3 \%$, natimortos $2,5 \%$, abortos $0,6 \%$, mortalidade neonatal $1,1 \%$, prematuridade $9,9 \%$, baixo peso ao nascer (BPN) 16,5\%, malformações congênitas 2,2\%. O número de gestantes HIV positivo triplicou ao longo do tempo, refletindo o aumento da prevalência da doença e a melhor identificação das pacientes. $\mathrm{O}$ diagnóstico da infecção pelo HIV antes da gestação aumentou de $30 \%$ em P1 para $45 \%$ em P3. A proporção de gestantes recebendo o tratamento combinado potente aumentou de zero em $\mathrm{P} 1$ para $88 \%$ em P3 com uma tendência significativa a ter uma carga viral abaixo do limite de detecção no parto nos últimos anos apesar de uma maior proporção de pacientes com doença mais avançada. O índice de cesarianas eletivas aumentou de $35 \%$ em P1 para $48 \%$ em P3. A taxa de transmissão perinatal global foi de $2,4 \%$ caindo de $3,5 \%$ em P1 para $1,6 \%$ em P3. Os desfechos neonatais tenderam a permanecer constantes ou a melhorar ao longo do tempo. Um discreto aumento dos índices de BPN e de malformações congênitas foi observado. Conclusões: Ao longo do período de estudo aumentou a proporção de gestantes HIV positivo com doença mais avançada e com padrão socioeconômico mais baixo. Por outro lado, a melhora da abordagem terapêutica dos pacientes infectados pelo HIV, associada a uma maior detecção de casos e maior acesso ao tratamento, resultou em uma redução da taxa de transmissão igualando-se à observada em países desenvolvidos com melhora concomitante de outros desfechos.

Palavras-chave: Transmissão maternoinfantil do HIV. Terapia anti-retroviral na gestação. Estudo de coorte de gestantes. HIV. Aids. Brasil.

\section{Introduction}

Until June 2005, 371,827 cases of AIDS in adults had been reported to the Brazilian Ministry of Health, of which 118,520 were women ${ }^{1}$. The proportion of HIV-infected women continues to increase in Brazil because of heterosexual transmission, and the male/female ratio was 2:1 in 2004 .

Since 1996, the National STD and AIDS Program offers HIV testing during prenatal care to all pregnant women in order to identify patients who would benefit from antiretroviral treatment to reduce motherto-child transmission (MTCT). Originally, prophylaxis with zidovudine according to PACTG 076 protocol guidelines ${ }^{2}$ was the standard of care and included avoidance of breastfeeding with provision of formula until infants were six months of age. From 2000 onwards, Brazilian guidelines included recommendations regarding administration of other antiretrovirals (ARV) during pregnancy. Triple ARV therapy became standard of care for patients with $\mathrm{CD} 4+\mathrm{T}$ cell counts $\leq 350$ cells $/ \mathrm{mm}^{3}{ }^{3}$. At present, perinatal HIV infection is responsible for almost all pediatric cases (children under 13 years of age) in Brazil ${ }^{1}$.

The mechanisms of HIV-1 MTCT are still not completely understood. Maternal viral load, CD4+ T cell counts and mode of delivery are some of the independent factors associated with transmission ${ }^{4-6}$. In a prior study conducted at our institution, we reported an overall MTCT rate of 3.6\%. Low birth weight was independently associated with a higher risk of perinatal transmission $(P=.007)$, whereas a longer duration of antiretroviral drugs during pregnancy was independently associated with lower risks of transmission $(P=.008)^{7}$. Other studies in Brazil showed similar perinatal transmission rates ${ }^{8-10}$.

Data from prospective cohort studies in developed countries have demonstrated changes over time in maternal profiles as well as progress in interventions to reduce MTCT $^{11-16}$. Advances in antiretroviral therapy have improved the therapeutic 
management of HIV disease with increasing prescription of combination antiretroviral therapy. Monotherapy is no longer considered an adequate treatment. Also, several studies have demonstrated that elective cesarean procedures reduce the risk of perinatal HIV transmission ${ }^{6,17}$.

The objective of this study was to describe trends in sociodemographic, immunological and virological profiles within a cohort of HIV-infected pregnant women followed at the Hospital dos Servidores do Estado (HSE) in Rio de Janeiro, and to describe interventions to decrease the risk of MTCT (antiretroviral therapy and mode of delivery) and transmission rates from January 1996 to December 2004.

\section{Methods}

\section{Study Design}

An ongoing observational cohort of HIVinfected pregnant women and their infants was established in 1996 at HSE, Rio de Janeiro, Brazil. HIV-positive pregnant women were referred to the Infectious Diseases Department at HSE from prenatal clinics in the metropolitan area of Rio de Janeiro. HSE is a 515-bed hospital in downtown Rio de Janeiro funded by the Brazilian Ministry of Health. The hospital is a referral center for the care of HIV infected adults, pregnant women and children in the city of Rio de Janeiro. Prenatal care is free and state supported. The Infectious Diseases Department at this hospital is responsible for the care of HIV-infected pregnant women and exposed infants, whereas the Pediatrics Department follows all diagnosed HIV-infected infants and children. Care of these patients is provided by a multi disciplinary team of researchers including infectious disease specialists (pediatric and adult infectious diseases specialists), obstetricians, nurses, psychologists, and social workers. HIV-infected pregnant women were followed up at HSE, and delivered their babies in the maternity ward for high-risk patients at the same hospital.
Inclusion criteria: 1) HIV-infected pregnant women at any gestational age with at least one prenatal visit and use of antiretroviral therapy who delivered between January 1, 1996 and December 31, 2004. Exclusion criteria: 1) HIV-infected pregnant women without prenatal care or who were identified at delivery and did not receive antiretroviral therapy. 2) Women who received only intrapartum zidovudine.

We conducted a retrospective cohort study of HIV-infected pregnant women receiving antenatal care at HSE. Medical charts of all women fitting the above criteria were reviewed anonymously without patient identifiers. The following data were abstracted from the records of the routine follow up of HIV-infected pregnant women and their children:

\section{A) Preliminary interview}

Data collected included: maternal socio-demographic and obstetric data with age, ethnicity, parity, prior history of prematurity, abortions and stillbirths, family income (as a multiple of the Brazilian minimum wage), total years of formal education completed, marital status and history of alcohol, tobacco and illicit drug use. Marital status was classified as single/widowed/separated or married/living as married. Maternal drug abuse, alcohol and tobacco were based on self-report and classified into never used, history of previous use before pregnancy and current use during the present gestation.

Mode of HIV exposure was classified as injecting drug use, blood transfusion, heterosexual contact with partner with known HIV infection or with high risk of HIV infection, and unknown.

HIV-related history, including previous knowledge of serostatus and use of antiretrovirals (ARV), detailed clinical, gynecological and obstetric histories were obtained at baseline.

B) Standardized procedures and laboratory assessments and exams

Laboratory assessments included a 
blood draw for confirmatory HIV testing, baseline CD4+ T cell count, baseline viral load, complete blood count with differential and platelets (CBC), biochemistry panel and serologies. HIV infection (as defined by the Brazilian Ministry of Health) required at least two positive serological tests on different samples, with confirmatory immunofluorescent (IFA), immunoblot (dot blot) or Western Blot assays $^{18}$. CD4+ $\mathrm{T}$ cell counts were measured by flow cytometry. The assays used for measurement of HIV-1 viral load were NASBA or NASBA Nuclisens (Organon Teknika) and PCR RNA (Amplicor Roche). Routine serologies included: treponemal (TPHA or FTA-ABS) and non-treponemal (VDRL) tests for syphilis, toxoplasmosis, rubella, CMV, Hepatitis B and C, and HTLV $1 / 2$. Basic biochemistry panel consisted of glucose, electrolytes, and complete liver and kidney function tests. Additional assessments were urinalysis and urine culture, stool exam for parasites; PPD; ultrasonographic examination for gestational age and evaluation of fetal abnormalities. Immunization against tetanus was provided when indicated.

\section{C) Maternal follow-up visits}

Women were evaluated by specialists in infectious diseases and obstetrics/gynecology monthly until 28 weeks of gestation, and then bimonthly until 36 weeks and weekly thereafter.

Plasma HIV RNA and CD4+ T cell counts were measured every three months, with the last evaluation done between 34 and 40 weeks gestation. CBC and basic biochemistry panel were obtained after ARV prescription (generally after 1 month) and ideally every 2 months. VDRL test for syphilis was repeated in the last trimester.

Maternal clinical disease staging was assigned at baseline and reviewed at $\geq 36$ weeks of gestation and performed with the use of the 1993 Revised Classification System for HIV Infection and Expanded Surveillance Case Definition for AIDS among Adolescents and Adults ${ }^{19}$.
Iron supplementation was offered and mothers were advised to avoid smoking and alcohol. Gestational age assignment was estimated according to the last menstrual period. The first trimester ultrasound was used to estimate gestational age when last menstrual period date was uncertain or in case of discrepancy between these two parameters. Neonatal physical examination by the Capurro method (a Brazilian version of the Ballard assessment) was also used to assess newborn gestational age $^{20}$. All maternal diagnoses related or not to HIV infection were recorded, including obstetric complications, sexually transmitted diseases (STDs), and clinical and serologic diagnoses.

\section{D) Mode of delivery}

Four categories of delivery were defined. Scheduled cesarean deliveries were those performed before the rupture of membranes and before onset of labor. Nonscheduled cesarean deliveries were performed after the rupture of membranes and/or onset of labor. Operative vaginal deliveries were those in which forceps and/ or vacuum extraction were used. Spontaneous vaginal deliveries were those in which neither forceps nor vacuum extraction was used. In the case of a vaginal mode of delivery, episiotomy and presence of perineal lacerations were registered. Data regarding time of rupture of membranes was also recorded. When a cesarean procedure was performed, data regarding the primary indication for the procedure was assessed and categorized as obstetrical indication or for prophylaxis of HIV-1 transmission. The mode of delivery was determined according to obstetric indications until 2000. Thereafter, scheduled cesarean procedures have been recommended for HIV-infected pregnant women with a peripheral blood viral load over 1,000 copies/ $\mathrm{mL}$ or an unknown viral load, after 34 weeks of gestational age ${ }^{3}$. For statistical analyses operative vaginal deliveries were grouped together with spontaneous vaginal deliveries. 
E) Profile of ARV usage during gestation, labor and delivery

Information on the use of ARV use was abstracted from medical records. Classes of ARV agents were classified as follows: ZDV monotherapy, combination ARV therapy with two nucleoside reverse transcriptase inhibitors (NRTI), and highly active antiretroviral therapy (HAART) with three or more agents, including at least one Protease Inhibitor (PI) or a nonnucleoside reverse transcriptase inhibitor (NNRTI). No women received monotherapy with an ARV drug other than ZDV. Patients were stratified according to the most complex regimen received during pregnancy.

\section{F) Maternal follow up visits (post-partum)}

Specialists in infectious diseases and obstetrics evaluated women after delivery. Routine follow-up visits were scheduled until 6 months post partum. ARV use was reevaluated and discontinued when prevention of mother-to-child transmission (PMTCT) was the indication for therapy. Women were counseled not to breastfeed and to use condoms and other contraceptive methods. Routine lab assessments consisted of plasma HIV RNA assays, CD4+ $\mathrm{T}$ cell counts, CBC and basic biochemistry panels every three months after delivery. Hepatitis B, influenza and pneumococcal 23 -valent vaccines were also provided when clinically indicated.

G) Children evaluation and follow-up visits

Newborns were evaluated by pediatricians and examined to determine characteristics at birth: sex, weight, length, head circumference, gestational age determined by the Capurro method, Apgar score (first and fifth minute), classification of intrauterine growth by adequacy of weight and gestational age by Bataglia and Lubchenco curves $^{21}$ and presence of malformations. Length of hospitalization following birth and evaluation of complications after birth were also registered. Infants were followed at the HSE by pediatricians specialized in infectious diseases until confirmation of the HIV infection status or serologic reversion, with visits every 15 days until six weeks of life, and every two months thereafter. Blood was collected for CBC, AST and ALT at 15 days; for CBC, AST, ALT and plasma HIV quantitative RNA assay at six weeks; CBC and plasma HIV quantitative RNA assay at three to four months; and HIV serology at 18 months. Plasma HIV quantitative assay at birth and HIV DNA PCR assays were performed on blood samples from some children. Children received immunizations according to Brazilian guidelines. Formula was provided free of charge to all mothers until babies were six months of age.

\section{H) Outcome Definitions/Study Definitions}

Premature Rupture of Membranes: Spontaneous rupture of membranes before onset of labor.

Preterm Delivery: Delivery before 37 completed weeks of gestation. Very preterm infants: Delivery before 34 completed weeks of gestation.

Miscarriage: Loss of a pregnancy with fetal weight under $500 \mathrm{~g}$.

Stillbirth: Death of a fetus after 22 weeks of gestation, and/ or death of a fetus weighing at least $500 \mathrm{~g}$.

Low birth weight: Infants with weight under $2500 \mathrm{~g}$ at delivery; very low birth weight: Infants under $1500 \mathrm{~g}$ at delivery.

Congenital syphilis: Clinical or epidemiological diagnosis according to Brazilian guidelines: Newborns from inadequately treated mothers with positive serology or newborns with VDRL titers greater than maternal titers ${ }^{22}$.

\section{I) Laboratory definition of infant's HIV diagnosis}

According to Brazilian guidelines ${ }^{3}$ : A child was defined as HIV-infected when positive HIV tests (positive HIV-1 DNA PCR or HIV-1 RNA levels over 10,000 copies/ $\mathrm{mL}$ ) were present in at least two blood samples taken on separate occasions or by persistently positive HIV antibody serologies after 18 months of age. A child was 
defined as HIV negative when HIV-1 DNA or RNA PCR did not show the antigen in at least two blood samples taken on separate occasions, with one determination after four months of age or by two negative HIV antibody serologies after 18 months of age. Children lost to follow-up or dead before clinical or serologic diagnosis were classified as having an indeterminate HIV status.

\section{Statistical Analyses}

Univariable comparisons for categorized variables were tested with the chisquare test for contingency tables. To define if such changes followed a trend, the chi-square test for trend as described by Altman ${ }^{23}$ was used and evaluated through the linear-by-linear association test. Wherever the chi-square test could not be used because the expected cell count was less than 5, Fisher exact test was used ${ }^{24}, 25$. Variables measured on a continuous scale were tested through analysis of variance (ANOVA) or by the non-parametric Kruskal-Wallis test. Trend was tested with the Spearman correlation coefficient. All statistical tests were two sided, and $P$ values $<.05$ were considered significant. Pregnancies that yielded multiple births were assessed as a single occurrence of HIV transmission if either one of the infants were HIV-infected and as a single non-occurrence of transmission if neither was HIV-infected. Analysis of maternal characteristics trends over the years was performed by stratification in three time periods: 1996-1998 (P1), 1999-2001 (P2) and 2002-2004 (P3). If a woman delivered more than one baby in different pregnancies during the study period, only information regarding the first pregnancy was considered, since the data collected from different pregnancies of the same woman are likely to be correlated. During the study period, 67 women had at least one subsequent pregnancy. Of these, 11 women became pregnant for a third time and were excluded from the analysis. When mother or infant data were missing for any variable, they were excluded from the analysis of that specific variable.

In the analysis of baseline T-CD4+ cell counts and viral load the first measurement collected just before ARV use was included in the analysis among women initiating therapy prior to pregnancy and in the patients initiating therapy during pregnancy. For statistical analysis purposes, all viral loads classified as undetectable by the assay used for measurement of HIV-1 RNA were recorded as under 400 copies/mL.

Data entry and management were carried out using SPSS (Statistical Package for Social Science, version 12.0, Chicago, Illinois). Data analysis was conducted using SPSS and the statistical package R Environment for Statistical Computing, version 2.0.1 (R Development Core Team, 2005).

\section{Results}

\section{Patient Characteristics}

Between January 1996 and December 2004, 642 women were enrolled in the cohort. Eighteen women $(2.8 \%)$ were lost to follow-up during gestation and 2 died before delivery. As of December 2004 there were 622 pregnancy outcomes: 591 singleton live births, 10 sets of twins, 1 set of triplets, 16 stillbirths, and 4 spontaneous abortions. The majority (85\%) of the HIV-infected pregnant women delivered at the clinical site (HSE) and only $14 \%$ at other hospitals in the city. Two patients delivered at home and one in the street.

Baseline characteristics of women at enrollment are shown in Table 1 and Table 2 , according to calendar year of presentation (three time periods of three years each). An increasing number of women were referred, and delivered at our hospital, with an increase from 15\% (98/642 women) in 1996-1998, to $37 \%(236 / 642)$ in $1999-2001$ to $48 \%$ (308/642) in 2002-2004.

No significant trends were identified for age, marital status, gestational history, 
Table 1 - Baseline maternal socio-demographic data

Tabela 1 - Dados socio-demográficos maternos no início do estudo

\begin{tabular}{|c|c|c|c|c|}
\hline Characteristics & $\begin{array}{c}1996-1998(P 1) \\
(n=98)\end{array}$ & $\begin{array}{c}\text { Calendar Period } \\
1999-2001(P 2) \\
(n=236)\end{array}$ & $\begin{array}{c}2002-2004(P 3) \\
(n=308)\end{array}$ & P-value \\
\hline \multicolumn{5}{|l|}{ Maternal age at entry (years) } \\
\hline Mean \pm SD & $27.97 \pm 5.55$ & $26.69 \pm 6.04$ & $26.89 \pm 6.12$ & .121 \\
\hline \multicolumn{5}{|l|}{ Ethnicity: N (\%) } \\
\hline White & $49(50.0)$ & 99 (41.9) & $117(38.1)$ & \\
\hline Black & $24(24.5)$ & $79(33.5)$ & $104(33.9)$ & $<.05^{\dagger}$ \\
\hline Mixed/mulatto & $25(25.5)$ & $58(24.6)$ & $86(28.0)$ & \\
\hline \multicolumn{5}{|l|}{ Income (Brazilian minimum wage) } \\
\hline Median & 2.50 & 2.00 & 2.00 & $<.005^{\|}$ \\
\hline \multicolumn{5}{|l|}{ Level of education (years) } \\
\hline Mean \pm SD & $7.94 \pm 4.10$ & $6.99 \pm 3.32$ & $7.05 \pm 3.41$ & $<.05^{\S}$ \\
\hline \multicolumn{5}{|l|}{ Marital status: N (\%) } \\
\hline Single/widow/separated & $27(28.7)$ & $72(30.8)$ & $88(28.6)$ & .846 \\
\hline Married/ Living as married & $67(71.3)$ & $162(69.2)$ & $220(71.4)$ & \\
\hline \multicolumn{5}{|l|}{ History of alcohol: N (\%) } \\
\hline Never used & $81(93.1)$ & $165(70.2)$ & $217(70.5)$ & \\
\hline Previous use before pregnancy & $2(2.3)$ & $36(15.3)$ & $60(19.5)$ & $<.001^{*}$ \\
\hline Current use & $4(4.6)$ & $34(14.5)$ & $31(10.1)$ & \\
\hline \multicolumn{5}{|l|}{ History of tobacco: N (\%) } \\
\hline Never used & $57(64.0)$ & $139(59.1)$ & $197(64.2)$ & \\
\hline Previous use before pregnancy & $4(4.5)$ & $35(14.9)$ & $50(16.3)$ & $<.05^{*}$ \\
\hline Current use & $28(31.5)$ & $61(26.0)$ & $60(19.5)$ & \\
\hline \multicolumn{5}{|l|}{ History of illicit drug use: $\mathrm{N}(\%)$} \\
\hline Never used & $84(94.4)$ & $178(75.7)$ & $235(76.5)$ & \\
\hline Previous use before pregnancy & $5(5.6)$ & $48(20.4)$ & $57(18.6)$ & $<.005^{\ddagger}$ \\
\hline Current use & - & $9(3.9)$ & $15(4.9)$ & \\
\hline
\end{tabular}

parity, history of prematurity, spontaneous abortions and stillbirths. There was a decline in the prevalence of Caucasian women from $50 \%$ in $\mathrm{P} 1$ to $38 \%$ in P3 $\left(\chi^{2}\right.$ trend $=3.89 ; P=.049)$. Over the same time period there was a statistically significant difference in the median of family incomes as a multiple of the Brazilian minimum wage, declining from 2.50 in P1 to 2.00 in P3 $(P<.005)$. Total years of formal education completed also declined from 7.93 in P1 to 7.05 in P3 $(P=.042)$.

Alcohol use was reported only in $4 \%$ (4/ 89) of women in P1, increasing to $15 \%$ (34/ $235)$ in $\mathrm{P} 2$ and to $10 \%(31 / 308)$ in $\mathrm{P} 3(P<$ $.001)$. There was a significant difference in the history of tobacco use during pregnancy declining from $32 \%(28 / 89)$ in $\mathrm{P} 1$ to $20 \%(60 / 307)$ in P3 $\left(\chi^{2}=12.57 ; P=.014\right)$. Il- licit drug use during current pregnancy increased from none between 1996-1998 to $5 \%(15 / 307)$ in $2002-2004(P<.005)$. Sexual exposure, as the source of HIV infection, represented the most common mode of HIV exposure in all periods and increased from $95 \%$ in $\mathrm{P} 1$ to $99 \%$ in $\mathrm{P} 3(P<$ .05). Over the same time period, the prevalence of injecting drug use and blood transfusion as the source of HIV infection, declined from $3.3 \%$ and $2.2 \%$ to $0.3 \%$ and $0.3 \%$, respectively.

The proportion of women in whom HIV infection had been diagnosed before pregnancy increased significantly over time from $30 \%$ in $\mathrm{P} 1$ to $45 \%$ in $\mathrm{P} 3\left(\chi^{2}=14.57 ; P=\right.$ $.001)$. Over the entire period of the study, there was a significant difference in the number of prenatal visits between the 
Table 2 - Baseline obstetric and other characteristics of HIV-infected pregnant women

Tabela 2 - Dados obstétricos de base e outras características das gestantes portadoras de HIV

\begin{tabular}{|c|c|c|c|c|}
\hline Characteristics & $\begin{array}{c}1996-1998(P 1) \\
(n=98)\end{array}$ & $\begin{array}{c}\text { Calendar Period } \\
1999-2001(P 2) \\
(n=236)\end{array}$ & $\begin{array}{c}2002-2004(P 3) \\
\quad(n=308)\end{array}$ & $P$-value \\
\hline \multicolumn{5}{|l|}{ Gestational history } \\
\hline$($ Mean \pm SD $)$ & $3.32 \pm 1.89$ & $3.30 \pm 2.17$ & $3.41 \pm 2.18$ & .707 \\
\hline \multicolumn{5}{|l|}{ Parity: N (\%) } \\
\hline Nulliparity & $28(28.6)$ & $57(24.2)$ & $86(27.9)$ & \multirow{3}{*}{.313} \\
\hline Primiparity & $29(29.6)$ & $81(34.3)$ & $80(26.0)$ & \\
\hline Multiparity ( $\geq 2$ ) & $41(41.8)$ & $98(41.5)$ & $142(46.1)$ & \\
\hline History of prematurity: $\mathrm{N}(\%)$ & $8(9.5)$ & $27(12.3)$ & $49(16.0)$ & .230 \\
\hline History of spontaneous abortions: N (\%) & $30(30.6)$ & $51(21.6)$ & $75(24.4)$ & .217 \\
\hline $\begin{array}{l}\text { History of stillbirth: } \mathrm{N}(\%) \\
\text { Mode of HIV exposure: } \mathrm{N}(\%)\end{array}$ & $5(5.3)$ & $10(4.3)$ & $19(6.2)$ & .616 \\
\hline Injecting drug use & $3(3.3)$ & $4(1.8)$ & $1(0.3)$ & \multirow{3}{*}{$<.05^{\dagger}$} \\
\hline Blood transfusion & $2(2.2)$ & $3(1.4)$ & $1(0.3)$ & \\
\hline Heterosexual transmission & $86(94.5)$ & $212(96.8)$ & $292(99.3)$ & \\
\hline \multicolumn{5}{|l|}{ Previous knowledge of HIV infection } \\
\hline \multicolumn{5}{|l|}{ Number of prenatal visits: } \\
\hline Mean \pm SD & $4.62 \pm 2.61$ & $5.24 \pm 2.69$ & $5.91 \pm 2.72$ & $<.001^{\ddagger}$ \\
\hline \multicolumn{5}{|l|}{ Gestational age at start of specialized care: } \\
\hline Mean \pm SD & $26.08 \pm 7.69$ & $24.47 \pm 8.28$ & $23.56 \pm 8.33$ & $<.05^{\ddagger}$ \\
\hline
\end{tabular}

three time periods, increasing from 4.62 visits in $\mathrm{P} 1$ to 5.24 visits in $\mathrm{P} 2$ and 5.91 visits in P3 $(P<.001)$. Besides, the gestational age at the start of specialized prenatal care decreased from 26.08 weeks in P1 to 23.56 in P3 $(P=.010)$.

\section{Immunological and virological characteristics}

Table 3 shows immunological and virological data of pregnant women at baseline and near delivery. CD $4+$ cell counts were stratified in three levels: 0-199, 200-499 and $\geq 500$ cells $/ \mathrm{mm}^{3}$ each. At entry, $13 \%(n=11)$ women had baseline CD4+ cell counts in the range of $0-199$ cells $/ \mathrm{mm}^{3}$ in $\mathrm{P} 1$ and $20 \%(\mathrm{n}=51)$ in $\mathrm{P} 3 . \mathrm{CD} 4+$ cell counts equal to or higher than 500 cells/ $\mathrm{mm}^{3}$ decreased from $38 \%(\mathrm{n}=33)$ to $29 \%$ $(n=72)$ when analyzing these two periods. At delivery, the proportion of women with serious imunosuppression (under 200 cells $\left./ \mathrm{mm}^{3}\right)$ increased from $8 \%(\mathrm{n}=8)$ in $\mathrm{P} 1$ to $13 \%(n=36)$ in $P 3$. CD4+ cell counts equal to or higher than 500 cells $/ \mathrm{mm}^{3}$ decreased from $51 \%(n=49)$ to $41 \%(n=117)$ in these two periods. There were no significant identifiable trends in the CD4+ cell counts before ARV usage or at delivery.

HIV RNA viral load became available for all the patients as of October 1997. Therefore, only 32/98 viral loads were obtained during the baseline visit and 53/98 at delivery in the 1996-1998 period. A statistical difference was observed in women with an undetectable viral load at delivery (under 400 copies $/ \mathrm{mL}$ ) increasing from $38 \%$ $(\mathrm{n}=84)$ in $\mathrm{P} 2$, to $65 \%(\mathrm{n}=184)$ in $\mathrm{P} 3\left(\chi^{2}=\right.$ 50.89; $P<.001)$. Among the remaining women with detectable viral loads there was also a statistical difference with a decrease of all stratified viral load levels towards the last period.

Profile of Antiretroviral Regimens usage before pregnancy, and during gestation, labor and delivery

Antiretroviral therapy was modified in 
Table 3 - Immunological and virological data of HIV-infected pregnant women enrolled in the cohort Tabela 3 - Dados imunológicos e virológicos das gestantes portadoras de HIV incluídas na coorte

\begin{tabular}{|c|c|c|c|c|}
\hline Characteristic & $1996-1998(\mathrm{P} 1)$ & $\begin{array}{l}\text { Calendar Period } \\
1999-2001(P 2)\end{array}$ & 2002- 2004 (P3) & P-value \\
\hline \multicolumn{5}{|c|}{ CDC classification: $\mathrm{N}(\%)$} \\
\hline$A$ & $69(70.4)$ & 169 (71.6) & $217(70.5)$ & \\
\hline B & $16(16.3)$ & $37(15.7)$ & $41(13.3)$ & .731 \\
\hline C & $13(13.3)$ & $30(12.7)$ & $50(16.2)$ & \\
\hline \multicolumn{5}{|c|}{$\mathrm{CD4}^{+}$cell count, cells $/ \mathrm{mm}^{3}$} \\
\hline \multicolumn{5}{|c|}{ Before antiretroviral use: $\mathrm{N}(\%)$} \\
\hline Mean \pm SD & $451.92 \pm 269.75$ & $418.23 \pm 225.22$ & $415.54 \pm 277.82$ & .258 \\
\hline Median & 398 & 390 & 361 & .323 \\
\hline 0-199 & $11(12.8)$ & $37(17.5)$ & $51(20.0)$ & \\
\hline $200-499$ & $42(48.8)$ & $110(52.1)$ & $131(51.4)$ & .402 \\
\hline$\geq 500$ & $33(38.4)$ & $64(30.3)$ & $72(28.6)$ & \\
\hline \multicolumn{5}{|l|}{ At Delivery: N (\%) } \\
\hline Mean \pm SD & $506.11 \pm 284.21$ & $497.94 \pm 253.99$ & $485.92 \pm 264.00$ & .517 \\
\hline Median & 506 & 465 & 453 & .491 \\
\hline 0-199 & $8(8.3)$ & $24(10.6)$ & $36(12.7)$ & \\
\hline $200-499$ & $39(40.6)$ & $101(44.7)$ & $131(46.1)$ & .490 \\
\hline$\geq 500$ & $49(51.0)$ & $101(44.7)$ & $117(41.2)$ & \\
\hline \multicolumn{5}{|c|}{ Viral load, copies/mL } \\
\hline \multicolumn{5}{|c|}{ Before antiretroviral use: $\mathrm{N}(\%)$} \\
\hline Mean \pm SD & $52265.44 \pm 84253.66$ & $41023.02 \pm 76957.12$ & $44078.74 \pm 109670.31$ & .649 \\
\hline Median & 14000.00 & 9300.00 & 6600.00 & .217 \\
\hline$\leq 400$ & $6(18.8)$ & $18(9.0)$ & $46(18.9)$ & \\
\hline $401-1,000$ & $1(3.1)$ & $18(9.0)$ & $24(9.8)$ & $<.05^{\|}$ \\
\hline $1,001-10,000$ & $6(18.8)$ & $70(35.2)$ & $67(27.5)$ & \\
\hline$>10,000$ & $19(59.4)$ & $93(46.7)$ & $107(43.9)$ & \\
\hline \multicolumn{5}{|l|}{ At Delivery: N (\%) } \\
\hline Mean \pm SD & $27019.62 \pm 72142.71$ & $14400.95 \pm 52610.18$ & $7892.50 \pm 46388.75$ & $<.05^{\ddagger}$ \\
\hline Median & 2300.00 & 885.00 & 400.00 & $<.001^{\S}$ \\
\hline$\leq 400$ & $18(34.0)$ & $84(37.8)$ & $184(64.6)$ & \\
\hline $401-1,000$ & $3(5.7)$ & $32(14.4)$ & $20(7.0)$ & $<.001^{*}$ \\
\hline $1,001-10,000$ & $16(30.2)$ & $61(27.5)$ & 54 (18.9) & \\
\hline$>10,000$ & $16(30.2)$ & $45(20.3)$ & $27(9.5)$ & \\
\hline
\end{tabular}

${ }^{*} \chi^{2}$ test; ${ }^{\dagger} \chi^{2}$ test for linear trend; ${ }^{\ddagger}$ ANOVA test for linear trend; ${ }^{5}$ Spearman correlation coefficient; $"$ Exact test.

"Teste $\chi^{2} ;{ }^{\dagger} \chi^{2}$ para tendência linear; ${ }^{\ddagger}$ ANOVA para tendência linear; ${ }^{\S}$ coeficiente de correlação de Spearman; "Teste Exato;

some women during pregnancy because of therapeutic failure, adverse reactions or clinician's decision to use a zidovudinecontaining regimen. Only near-delivery final regimens were analyzed.

Few women were taking ARV for their own health before they became pregnant in $\mathrm{P} 1$. In contrast, an increasing number of antiretroviral-experienced patients were observed in the last two periods. Use of dual nucleoside NRTI-containing therapy decreased over the years (from 67\% in P1,
$56 \%$ in $\mathrm{P} 2$ to $12 \%$ in P3). None of the women were taking ARV containing NNRTI or PI in the first period. Use of NNRTI-containing regimens increased over time (15\% in P2 and 53\% in P3). Also an increasing number of women were taking PI-containing regimens in P2 (24\%) and P3 (35\%) when they became pregnant. There was a statistically significant difference between these periods $(P<.001)$.

Zidovudine monotherapy was used by $55 \%$ of the cohort in P1 decreasing to $11 \%$ 
in P3. The proportion of pregnant women receiving HAART increased over the course of the last two periods, consistent with the introduction of HAART for PMTCT of HIV according to Brazilian guidelines. In P2, $36 \%$ received HAART. This proportion increased to $84 \%$ in P3. Most HAART containing regimens consisted of zidovudine and lamivudine plus nelfinavir or nevirapine.

In the analysis of ARV usage only for the purpose of prevention of MTCT, zidovudine monotherapy or double therapy with NRTI was prescribed in $100 \%$ of cases in P1 decreasing to 92\% in P2 and $25 \%$ in P3 $\left(\chi^{2}=151,97 ; P<.001\right)$. Of the 250 women who initiated HAART during P3, $45 \%(112 / 250)$ discontinued the therapy during the post-partum period based in improved pre-HAART immunologic and clinical data according to Brazilian guidelines for prophylaxis of MTCT of HIV.

With the exclusion of women who became pregnant while on ARV, there was no statistically significant difference in the gestational age at initiation of ARV between the three periods: $\mathrm{P} 1=26.2$ weeks, $\mathrm{P} 2=25.4$ weeks and $\mathrm{P} 3=25.4$ weeks $(P=.359)$. When women who became pregnant while taking ARV were included, a linear trend appeared in mean duration of ARV exposure, ranging from 14.48 weeks in $\mathrm{P} 1$ to 17.13 weeks in P3 $(P=.041)$. Compliance with intrapartum and postpartum prophylaxis with zidovudine therapy increased over time from $89 \%$ in $\mathrm{P} 1,95 \%$ in $\mathrm{P} 2$ to $98 \%$ in P3 $(P<.005)$.

\section{Mode of delivery and newborn outcomes}

A significant increase in the proportion of women who delivered by scheduled cesarean procedures was observed, from $35 \%$ in the first period to $48 \%$ in the last period $\left(\chi^{2}=11.31 ; P=.023\right)$. This was accompanied by a concomitant decrease in the proportion of vaginal deliveries (Table 4 ). The proportion of nonscheduled cesarean deliveries remained relatively constant over time. Primary indication for scheduled cesarean procedures changed over time with an increasing indication of the procedure for PMTCT $\left(\chi^{2}=43.76 ; P=<.001\right)$. Median gestational age at delivery was 39 weeks in all three periods. When analyzing time trends, there was no statistical difference among preterm deliveries $(P=.633)$, the interval between rupture of membranes and delivery $(P=.139)$ and the integrity of the perineum among women who delivered vaginally $(P=.943)$.

Within the cohort, the presence of premature (under 37 weeks) and very premature deliveries (under 34 weeks) did not differ significantly over time as seen in Table 4. Mean birth weight decreased with a linear trend towards the last period $(P=.038)$. Also a birth weight under 2,500 g was observed in $14 \%$ of newborns in P1 and in $18 \%$ of newborns in P3 $(P=.438)$. Diagnoses of congenital syphilis or other complications were similar over the periods. Diagnoses of congenital malformations increased from $1.4 \%$ in $\mathrm{P} 2$ to $3.4 \%$ in $\mathrm{P} 3$ without statistical difference $(P=.094)$. A total of 13 distinct malformations were observed, with none occurring more than once. Stratification by type of antiretroviral exposure did not identify any particular trend.

\section{Mother-to-child HIV transmission rate}

The overall rate of vertical transmission was $2.4 \%$ (13/539). HIV vertical transmission rates were $3.5 \%(3 / 85)$ in $\mathrm{P} 1$ and remained unchanged in P2 (3.0\%) (6/199), when incidence began to decrease, reaching $1.6 \%(4 / 255)$ in P3 $(P=.270)$. Excluding women lost to follow-up before delivery $(n=18)$, death during gestation $(n=2)$, spontaneous abortions $(n=4)$ and stillbirths $(n=16)$ : of the 64 infants whose HIV status was not determined, $53(83 \%)$ were due to loss to follow-up, and 11 (17\%) died before four months of age, with 6 infants dying before one month of age (neonatal mortality was $6 / 550$ or $11 / 1000$ live births).

\section{Discussion}

In nearly a decade of observation, over 
Table 4 - Mode of delivery and newborn outcomes

Tabela 4 - Tipo de parto e características do recém-nascido

\begin{tabular}{|c|c|c|c|c|}
\hline Variables & $1996-1998$ (P1) & $\begin{array}{l}\text { Calendar Period } \\
1999-2001(P 2)\end{array}$ & 2002- 2004 (P3) & P-value \\
\hline \multicolumn{5}{|l|}{ Gestational age at delivery: $\mathrm{N}(\%)$} \\
\hline$<34$ weeks & $5(5.4)$ & $4(1.8)$ & $8(2.8)$ & .232 \\
\hline$<37$ weeks & $9(9.7)$ & $18(8.3)$ & $31(10.8)$ & .621 \\
\hline Mean \pm SD & $38.21 \pm 2.22$ & $38.18 \pm 2.93$ & $38.06 \pm 2.88$ & .650 \\
\hline Median & 39 & 39 & 39 & .379 \\
\hline HIV MTCT rate & $(3 / 85)(3.5 \%)$ & $(6 / 199)(3.0 \%)$ & $(4 / 255)(1.6 \%)$ & .270 \\
\hline \multicolumn{5}{|l|}{ Mode of delivery: $\mathrm{N}(\%)$} \\
\hline Spontaneous vaginal delivery & $38(41.3)$ & $103(45.8)$ & $100(34.6)$ & \\
\hline Scheduled cesarean & $32(34.8)$ & $91(40.4)$ & $138(47.8)$ & $<.05^{*}$ \\
\hline Nonscheduled cesarean & $22(23.9)$ & $31(13.8)$ & $51(17.6)$ & \\
\hline \multicolumn{5}{|l|}{ Rupture of membranes before delivery: $\mathrm{N}(\%)$} \\
\hline$<4$ hours & $69(81.2)$ & $177(88.1)$ & $241(89.3)$ & .139 \\
\hline$\geq 4$ hours & $16(18.8)$ & $24(11.9)$ & $229(10.7)$ & \\
\hline \multicolumn{5}{|l|}{ Perineum (vaginal delivery): $\mathrm{N}(\%)$} \\
\hline Intact & $79(80.6)$ & $194(82.2)$ & $252(81.8)$ & .943 \\
\hline Episiotomy or laceration & $19(19.4)$ & $42(17.8)$ & $56(18.2)$ & \\
\hline \multicolumn{5}{|l|}{ Primary indication for C -section: N (\%) } \\
\hline Obstetrical indication & $53(100.0)$ & $66(57.4)$ & $93(49.7)$ & $<.001^{*}$ \\
\hline Prevention of MTCT & - & $49(42.6)$ & $94(50.3)$ & \\
\hline \multicolumn{5}{|l|}{ Newborn Outcomes: N (\%) } \\
\hline \multicolumn{5}{|l|}{ Birth weight $(g)$} \\
\hline Mean \pm SD & $3098.97 \pm 623.29$ & $3050.84 \pm 602.58$ & $2946.24 \pm 591.17$ & $<.05^{\dagger}$ \\
\hline$\geq 2500$ & $75(86.2)$ & $188(85.1)$ & $239(81.6)$ & \\
\hline$<2500$ & $12(13.8)$ & $33(14.9)$ & $54(18.4)$ & .438 \\
\hline \multicolumn{5}{|l|}{ Baby's sex } \\
\hline Male & $48(53.9)$ & $102(46.2)$ & $149(49.5)$ & .447 \\
\hline Female & $41(46.1)$ & $119(53.8)$ & $152(50.5)$ & \\
\hline \multicolumn{5}{|l|}{ Birth Weight corrected for gestational age } \\
\hline Small for gestational age ( $<10$ th percentile) & $6(6.9)$ & $16(7.4)$ & $30(10.5)$ & \\
\hline Appropriate for gestational age & $72(82.8)$ & $177(81.9)$ & $238(83.2)$ & .293 \\
\hline Large for gestational age ( $>90$ th percentile) & $9(10.3)$ & $23(10.6)$ & $18(6.3)$ & \\
\hline Infant Complications & $24(26.1)$ & $38(17.8)$ & $63(21.8)$ & .234 \\
\hline Infant Malformations & 0 & $3(1.4)$ & $10(3.4)$ & .094 \\
\hline Congenital syphilis & $4(4.5)$ & $9(4.1)$ & $12(4.1)$ & 1.0 \\
\hline
\end{tabular}

Abbreviations: MTCT: Mother-to-child transmission; ${ }^{*} \chi^{2}$ test; ${ }^{\dagger}$ ANOVA test for linear trend.

Abreviações: MTCT:Transmissão materno-infantil; ${ }^{*}$ Teste $\chi^{2} ;{ }^{+}$ANOVA para tendência linear.

600 pregnancies of HIV- infected women were followed at a single referral, public tertiary center in Rio de Janeiro, Brazil. Overall, maternal and fetal outcomes were good despite the underlying diagnosis. Maternal mortality was $0.3 \%$, with $2.5 \%$ stillbirth deliveries, and $0.6 \%$ miscarriages. Neonatal outcomes, particularly, did not differ significantly from that of the general population of similar socio-economic background over the same time period in the city of Rio de Janeiro ${ }^{26}$. Notably, the proportion of miscarriages, stillbirth deliveries and maternal mortality remained constant over nine years in this population despite increasing use of HAART and a much higher percentage of immunocompromised patients. This is likely attributable to improved prenatal care for HIVinfected women and in particular to the 
effectiveness of HAART in treating maternal disease and preventing HIV MTCT. The number of women followed up tripled at HSE between 1996 to 2004, most likely due to the increasing identification of HIV-infected women during pregnancy; a consequence of significant citywide efforts for improving voluntary testing and counseling for HIV during prenatal care. In addition, increasing referral of patients and an increasing epidemic in the city could account for the higher number of pregnant HIV-infected patients referred to this center.

Over time, the socio-economic status (SES) of patients declined, as did the level of education, reflecting an increasing frequency in HIV infection among more economically deprived patients. A decline in the proportion of HIV-infected Caucasian patients also reflected a similar trend, since, due to economic disparities, nonCaucasians comprise the majority of patients of lower SES in Brazil. This is consistent with data gathered by the Brazilian Ministry of Health, reflecting a so-called "pauperization trend of the HIV epidemic in Brazil" ${ }^{1}$. Alcohol use by pregnant women doubled over nine years, although tobacco use dropped over time. Recreational drug use was infrequent overall, although it did increase from none to $5 \%$ over the observation period. The number of women infected by injecting drug use, however, decreased to $<0.3 \%$. Thus, sexual exposure remained the predominant pattern of HIV acquisition of infection throughout.

The proportion of women diagnosed during pregnancy increased from one third to over $50 \%$ of women in later years, similar to the increasing patterns of recognition of HIV-infected women during pregnancy observed in developed countries ${ }^{13-}$ ${ }^{15}$. The number of prenatal visits also increased slightly over the years to nearly six per pregnancy, potentially reflecting better prenatal care in this population. Women also started seeking prenatal care earlier with a change in a mean of 26 weeks to 23 weeks in latter years.
As previously noted, the number of immunocompromised patients (with CD4 cell counts under 200 cells $/ \mathrm{mm} 3$ ) increased over time, from 13 to $20 \%$ (baseline levels) and 8 to $13 \%$ (delivery levels). Although HIV virus loads only became available in the second year of analysis, there was a significant trend towards women delivering at much lower HIV RNA levels in later periods, reflecting the broad use of HAART. The increase in undetectable HIV RNA levels at delivery was in excess of $65 \%$ with nearly $2 / 3$ of women having undetectable levels at delivery in later years. The successful suppression of virus load during pregnancy achieved within this cohort is comparable to that obtained in developed countries ${ }^{28}$.

Over the years, there was a shift in ARV use to HAART similarly to what has been observed worldwide in developed countries $^{4,11,13,28,30}$, with $87 \%$ of pregnant women receiving either PI-based or NNRTI-based HAART in later years. For women initiating therapy during pregnancy, $84 \%$ were prescribed HAART and only $11 \%$ received ZDV monotherapy in later years. This was very different from the earlier time points, where $96 \%$ of patients received either ZDV monotherapy or dual therapy. While gestational age at start of HAART did not change over time, remaining around 25 to 26 weeks, the mean length of ARV use increased from 14 to 17 weeks over time. In addition, the proportion of women receiving intravenous ZDV intrapartum increased from $89 \%$ to $98 \%$, also reflecting progress in the prenatal care of HIV-infected women.

In this cohort of over 600 pregnancies, prematurity did not differ significantly over time. Term deliveries comprised $90 \%$ of deliveries in the earlier years and $89 \%$ of deliveries in later years. Overall, the presence of prematurity was lower than that noted in other studies ${ }^{31,32}$ and did not show any statistically significant increases, contrary to selected studies ${ }^{32}$, and consistent with other publications of large U.S. cohorts $^{33}$. 
Not unexpectedly, scheduled cesarean deliveries increased over time from $35 \%$ to $48 \%$. Prevention of HIV MTCT was an indication for a scheduled cesarean procedure in $50 \%$ of circumstances in later years. Birth weight, however, did show a trend towards decline in later years. Infants less than $2.5 \mathrm{~kg}$ comprised $14 \%$ of the cohort in earlier years as opposed to $18 \%$ in later years. The reason for lower infant weights is uncertain. It does not appear that prematurity accounted for this observation. Women delivering in later years had proportionally higher immune suppression and advanced HIV disease as compared to women delivering in earlier years. This could lead to more placental insufficiency with smaller babies being delivered. Whether there is a potential impact of higher ARV use (and HAART) on birth weight remains to be determined. In the general population in Rio de Janeiro, birth weights under $2.5 \mathrm{~kg}$ accounted for approximately $9 \%$ of all deliveries in public hospitals within the metropolitan area in $2004^{26}$. This proportion, however, did not change significantly in 10 years.

Slightly higher rates of congenital malformations were observed in later years, with a noted increase from 0 to $3.4 \%$. The figures are higher than those observed in the general population of infants born in Rio de Janeiro in 2004 (0.8\%), although in this database, the presence of congenital malformation rates was not available for $9 \%$ of births recorded ${ }^{26}$. From 1999 to 2004, a moderate increase in congenital malformation $(0.3$ to $0.8 \%)$ was observed in the general population. No consistent pattern of malformation was observed within our cohort, but the higher rates of congenital malformations observed in later years needs to be evaluated in additional studies.
Very positive maternal and infant outcomes were identified in the HSE cohort of mothers and infants. The increasing use of HAART during pregnancy was highly successful in the prevention of HIV MTCT. Perinatal transmission rates declined from $3.5 \%$ in the first two periods to $1.6 \%$ in the latter years. A similar decrease has been observed in the Southeast region of Brazil from $8.6 \%$ in 2000 to $3.7 \%$ in $2002^{27}$. Since breastfeeding is contraindicated in Brazil and provision of formula is the rule, postnatal transmission by lactation is extremely rare. MTCT rates $<2 \%$ are highly consistent with data from randomized clinical trials such as PACTG 316, which also reported transmission rates of $1.4 \%$ with the use of HAART ${ }^{28}$. Data from this cohort provides sufficient evidence that mid-developed countries such as Brazil can attain virtually identical success rates with the use of HAART during pregnancy for PMTCT with minimal to no adverse events noted, as observed in the United States and Western Europe. Despite the expansion of the epidemic to more impoverished segments of society and a larger number of patients with advanced HIV disease becoming pregnant, maternal and neonatal outcomes did not change significantly over time, indicating that improved prenatal care to HIV-infected women is highly feasible and translates into lower infection rates, decreased morbidities and prolonged survival.

The authors declare that there are no conflicts of interest. The study was approved by the Research Ethics Committee of the Hospital dos Servidores do Estado, Rio de Janeiro, Brazil. All documents were submitted to the Secretariat of the Brazilian Journal of Epidemiology. There was no financial support. 


\section{References}

1. Brasil. Programa de Nacional DST/AIDS. Boletim Epidemiológico de AIDS DST - ANO II nº01 - 01 à 26 Semanas epidemiológicas janeiro a junho de 2005 Brasília, DF; 2005. Available at: http://www.aids.gov.br/ data/documents/storedDocuments/\%7BB8EF5DAF23AE-4891-AD36-1903553A3174\%7D/\%7BED005A4214BE-4F7E-98A7-E6AD7CD9A76D\%7D/BOLETIM.pdf. Retrieved June 04, 2006.

2. Connor EM, Sperling RS, Gelber R, Kiselev P, Scott G, O'Sullivan MJ, et al. Reduction of maternal-infant transmission of human immunodeficiency virus type 1 with zidovudine treatment. Pediatric AIDS Clinical Trials Group Protocol 076 Study Group. N Engl J Med 1994 Nov 3; 331(18): 1173-80.

3. Brasil, Programa Nacional de DST/AIDS. Recomendações para Profilaxia da Transmissão Vertical do HIV e Terapia Anti-Retroviral em Gestantes. Brasília, DF; 2004. Available at: http://www.aids.gov.br/data/documents/ storedDocuments/\%7BB8EF5DAF-23AE-4891-AD361903553A3174\%7D/\%7B513DDA72-7E9D-4E2C-806E8D1E0B66ACC5\%7D/ConsensoGestante2004.pdf. Retrieved June 04, 2006.

4. European Collaborative Study. Mother-to-child transmission of HIV infection in the era of highly active antiretroviral therapy. Clin Infect Dis 2005 Feb 1; 40(3): 458-65.

5. European Collaborative Study. HIV-infected pregnant women and vertical transmission in Europe since 1986. European collaborative study. Aids 2001; 15(6): 761-70.

6. The International Perinatal HIV Group. The mode of delivery and the risk of vertical transmission of human immunodeficiency virus type 1: A meta-analysis of 15 prospective cohort studies. N Engl J Med 1999; 340(13): 977-87.

7. Joao EC, Cruz ML, Menezes JA, Matos HJ, Calvet GA, d'Ippolito MM, et al. Vertical transmission of HIV in Rio de Janeiro, Brazil. Aids 2003; 17(12): 1853-5.

8. Nogueira SA, Abreu T, Oliveira R, Araujo L, Costa T, Andrade M, et al. Successful prevention of hiv transmission from mother to infant in Brazil using a multidisciplinary team approach. Braz J Infect Dis 2001; 5(2): 78-86.

9. Kreitchmann R, Fuchs SC, Suffert T, Preussler G. Perinatal HIV-1 transmission among low income women participants in the HIV/AIDS Control Program in Southern Brazil: a cohort study. BJOG: An International Journal of Obstetrics \& Gynecology 2004; 111(6): 579-84.

10. Matida LH, da Silva MH, Tayra A, de Menezes Succi RC, Gianna MC, Goncalves A, et al. Prevention of mother-tochild transmission of HIV in Sao Paulo State, Brazil: an update. Aids 2005; 19(S4): S37-41.
11. Ahdieh-Grant L, Tarwater PM, Schneider MF, Anastos K, Cohen M, Khalsa A, et al. Factors and Temporal Trends Associated With Highly Active Antiretroviral Therapy Discontinuation in the Women's Interagency HIV Study. $J$ Acquir Immune Defic Syndr 2005; 38(4): 500-3.

12. Minkoff H, Ahdieh L, Watts H, Greenblatt RM, Schmidt J, Schneider M, et al. The relationship of pregnancy to the use of highly active antiretroviral therapy. Am J Obstet Gynecol2001; 184(6): 1221-7.

13. Cooper ER, Charurat M, Burns DN, Blattner W, Hoff R. Trends in antiretroviral therapy and mother-infant transmission of HIV. The Women and Infants Transmission Study Group. J Acquir Immune Defic Syndr 2000; 24(1): 45-7.

14. Fiscus SA, Adimora AA, Funk ML, Schoenbach VJ, Tristram D, Lim W, et al. Trends in interventions to reduce perinatal human immunodeficiency virus type 1 transmission in North Carolina. Pediatr Infect Dis J 2002; 21(7): 664-8.

15. The Italian Collaborative Study on HIV infection in pregnancy. Mother-to-child transmission of human immunodeficiency virus in Italy: Temporal trends and determinants of infection. Hum Reprod 1999; 14(1): 242 6 .

16. European Collaborative Study. Pregnancy-related changes in the longer-term management of HIV-infected women in Europe. Eur J Obstet Gynecol Reprod Biol 2003; 111(1):3-8.

17. The European Mode of Delivery Collaboration. Elective caesarean section versus vaginal delivery in prevention of vertical HIV-1 transmission: a randomised clinical trial. Lancet 1999; 353(9158): 1035-9.

18. Brasil, Ministério da Saúde. Diário Oficial da União. PORTARIA No 59 - 28 de Janeiro de 2003 - Novo Algoritmo para o Diagnóstico sorológico da Infecção pelo HIV. Brasília, DF; 2003. Edição Número 22 de 30/01/2003. Available at: http://www.aids.gov.br/data/documents / storedDocuments/\%7BB8EF5DAF-23AE-4891-AD361903553A3174\%7D/\%7B41015A25-0442-4811-9AD006735E0AC199\%7D/Portaria_59_novo_algoritmo.pdf. Retrieved June 04, 2006.

19. Centers for Disease Control and Prevention. 1993 Revised Classification System for HIV Infection and Expanded Surveillance Case Definition for AIDS among Adolescents and Adults. MMWR Recomm Rep 1992; 41(RR-17): 1-19.

20. Capurro H, Konichezky S, Fonseca D, Caldeyro-Barcia R. A simplified method for diagnosis of gestational age in the newborn infant. J Pediatr 1978; 93(1): 120-2.

21. Battaglia FC, Lubchenco LO. A practical classification of newborn infants by weight and gestational age. J Pediatr 1967; 71(2): 159-63. 
22. Paz LC, Pereira GF, Pinto VM, Medeiros MG, Matida LH, Saraceni V, et al. New case definition of congenital syphilis for epidemiological surveillance purposes in Brazil, 2004. Rev Soc Bras Med Trop 2005; 38(5): 446-7.

23. Altman DG. Practical statistics for medical research. 1st ed. London: Chapman \& Hall, 1991.

24. Mehta CR, Patel NR: Algorithm 643. FEXACT: A Fortran subroutine for Fisher's exact test on unordered r*c contingency tables. ACM Transactions on Mathematical Software 1986; 12: 154-61.

25. Clarkson DB, Fan Y, Joe H: A Remark on Algorithm 643: FEXACT: An Algorithm for Performing Fisher's Exact Test in $\mathrm{r} \times \mathrm{c}$ Contingency Tables. ACM Transactions on Mathematical Software 1993, 19: 484-8.

26. Secretaria Municipal de Saúde. Gerência de Informações Epidemiológicas. Série Histórica dos Nascimentos na Cidade do Rio de Janeiro - 1993 a 2004. 17/04/2006. Available at: http://www.saude.rio.rj.gov.br/saude/ pubsms/. Retrieved June 04, 2006.

27. Succi RCM. Grupo Brasileiro de Estudo para Avaliar a Transmissão Vertical do HIV. Estudo Multicêntrico para Avaliação da Taxa de Infecção da Transmissão Vertical do HIV. XXXII Congresso Brasileiro de Pediatria, São Paulo, Brasil, Outubro de 2003 [Resumo OR 840].

28. Dorenbaum A, Cunningham CK, Gelber RD, Culnane M, Mofenson L, Britto P, et al. Two-dose intrapartum/ newborn nevirapine and standard antiretroviral therapy to reduce perinatal HIV transmission: a randomized trial. Jama 2002; 288(2): 189-98.
29. Suy A, Martinez E, Coll O, Lonca M, Palacio M, de Lazzari E, et al. Increased risk of pre-eclampsia and fetal death in HIV-infected pregnant women receiving highly active antiretroviral therapy. Aids 2006; 20(1): 59-66.

30. Cooper ER, Charurat M, Mofenson L, Hanson IC, Pitt J, Diaz C, et al. Combination antiretroviral strategies for the treatment of pregnant HIV-1-infected women and prevention of perinatal HIV-1 transmission. JAcquir Immune Defic Syndr 2002; 29(5): 484-94.

31. Morris AB, Dobles AR, Cu-Uvin S, Zorrilla C, Anderson J, Harwell JI, et al. Protease inhibitor use in 233 pregnancies. J Acquir Immune Defic Syndr 2005; 40(1): 30-3.

32. Thorne C, Patel D, Newell ML. Increased risk of adverse pregnancy outcomes in HIV-infected women treated with highly active antiretroviral therapy in Europe. Aids 2004; 18(17): 2337-9.

33. Tuomala RE, Watts DH, Li D, Vajaranant M, Pitt J, Hammill H, et al. Improved Obstetric Outcomes and Few Maternal Toxicities Are Associated With Antiretroviral Therapy, Including Highly Active Antiretroviral Therapy During Pregnancy. J Acquir Immune Defic Syndr 2005; 38(4): 449-73.

Recebido em: 22/09/06 Versão final reapresentada em: 04/07/07 Aprovado em: 24/07/07 